\title{
PENGEMBANGAN QR CODE SCANNER BERBASIS ANDROID UNTUK SISTEM INFORMASI MUSEUM SONOBUDOYO YOGYAKARTA
}

\author{
Bambang Sugiantoro dan Fuad Hasan \\ Teknik Informatika UIN Sunan Kalijaga Yogyakarta \\ Jl Adisucipto Yogyakarta \\ email : bambang.sugiantoro@uin-suka.ac.id
}

\begin{abstract}
Abstrak
Seiring dengan berkembangnya teknologi smartphone, museum sebagai aset pemerintah juga harus menyesuaikan dalam menampilkan koleksinya. Aplikasi QR Code Scanner yang dibangun berbasis Android menggunakan ZBar Library mempunyai fitur Scanner, Bookmark, tentang Museum Sonobudoyo, dan menampilkan foto koleksi secara 3D Rotate. Semua fitur dalam aplikasi ini dapat berjalan dengan baik. Hasil pengujian alpha adalah semua proses dalam aplikasi berhasil dijalankan saat dilakukan pengujian. Pengujian beta pada fungsionalitas aplikasi didapatkan 100\% responden menyatakan "Ya", dan 0\% responden menyatakan "Tidak". Sedangkan pengujian beta pada antarmuka sistem dengan hasil skor yaitu 66.4 yang berada pada skala rating antara $54.41-67.20$ adalah puas
\end{abstract}

Kata kunci : QR code, Android, smartphones,

Abstract

Along with the development of smartphone technology, the museum as an asset of the government also had to adjust the display collection. QR Code Scanner application built using Android-based ZBar Library features the Scanner, Bookmark, about Sonobudoyo, and display photos in 3D Rotate collection. All features in these applications can be run properly. Results of alpha testing is all in the application process successfully run during testing. Beta testing the application functionality obtained $100 \%$ of respondents said "Yes", and $0 \%$ of respondents said "No". While beta testing the system interface with the score is 66.4 which is located on the rating scale between $54.41-67.20$ is satisfied

Keyword: QR code, Android, smartphones

\section{Pendahuluan}

Museum Sonobudoyo sudah terdapat Sistem Manajemen Koleksi Museum tetapi hanya orang-orang tertentu yang dapat mengakses sistem tersebut. Maka dari itu dibutuhkan aplikasi untuk menampilkan informasi benda koleksi pemer yang digunakan pemandu dan pengunjung untuk melihat informasi lebih detail tentang benda-benda koleksi pamer. Sehingga pemandu dan pengunjung mendapatkan informasi lebih detail tentang informasi benda-benda koleksi pamer.

Menurut hasil survei dari Gartner, sebuah perusahaan riset dan konsultan Teknologi Informasi (TI) ternama terlihat adanya peningkatan pangsa pasar Android lebih dari $700 \%$ dalam tahun 2010 yang memiliki nominal smartphone terjual sebanyak 67.224.500. Hal ini menunjukkan besarnya potensi Android di masa depan.

Kode QR adalah suatu jenis kode matriks atau kode batang dua dimensi yang dikembangkan oleh Denso Wave, sebuah divisi Denso Corporation yang merupakan sebuah perusahaan Jepang dan dipublikasikan pada tahun 1994. Agar dapat membaca QR Code diperlukan sebuah pembaca atau pemindai berupa software yaitu QR Code Reader atau QR code Scanner yang harus diinstal pada perangkat telepon mobile.QR merupakan singkatan dari 
quick response atau respons cepat, yang sesuai dengan tujuannya adalah untuk menyampaikan informasi dengan cepat dan mendapatkan respons yang cepat pula. Berbeda dengan kode batang, yang hanya menyimpan informasi secara horizontal, kode QR mampu menyimpan informasi secara horizontal dan vertikal (Soon, 2008).

Berdasarkan permasalahan akan membangun QR Code Scanner berbasis Android yang mempunyai fitur QR Code Scanner, Bookmark, tentang Sonobudoyo, dan 3D Rotate untuk menampilakan detail foto koleksi. Tentunya pemandu dan pengunjung akan mendapatkan informasi tersebut secara realtime di lokasi Museum Negeri Sonobudoyo.

\section{Metode Perancangan}

\subsection{Diagram Use Case}

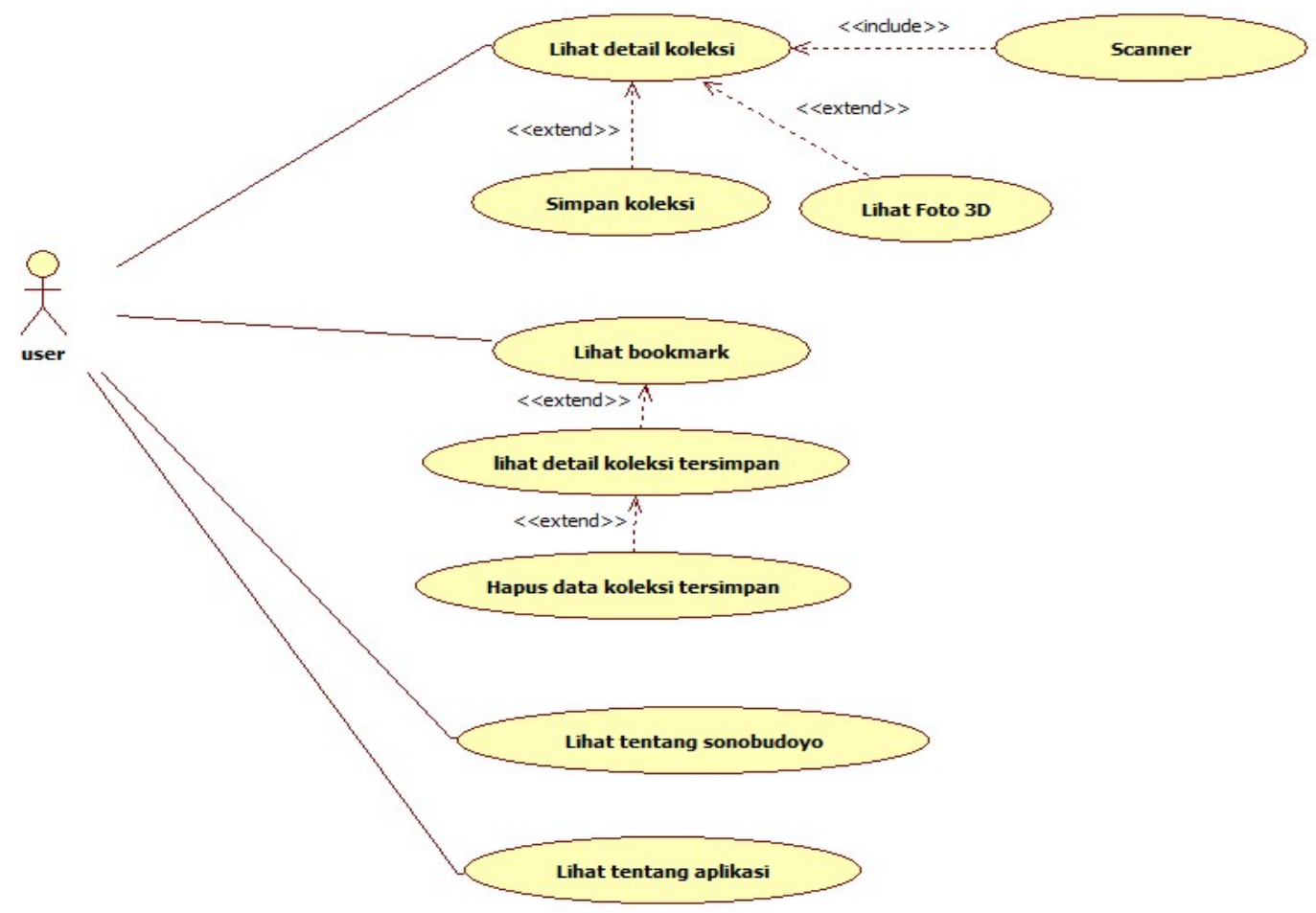

Gambar 2.1 Diagram Use Case

\subsection{Diagram Aktivitas}

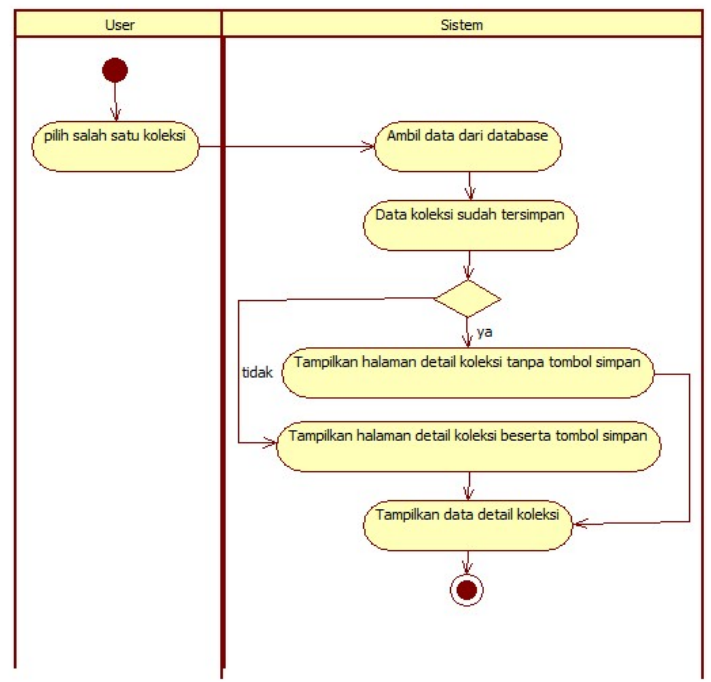




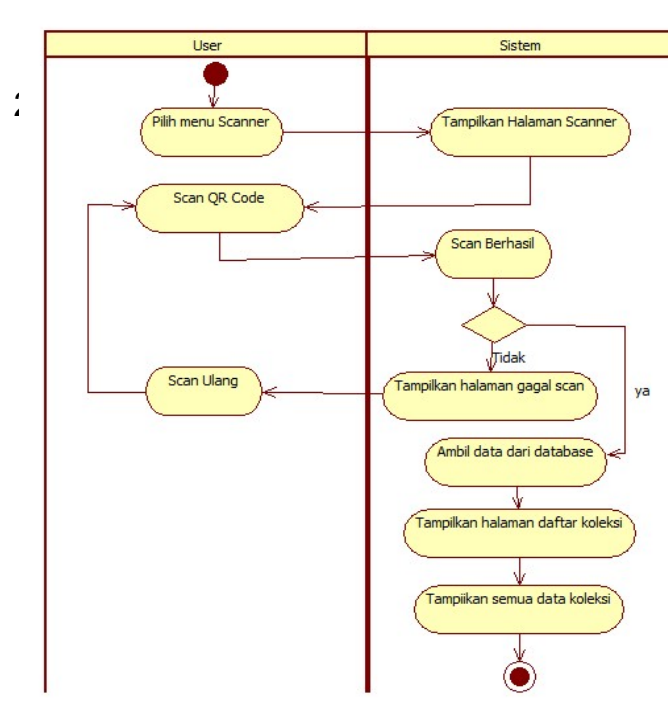

gram Aktivitas Scanner
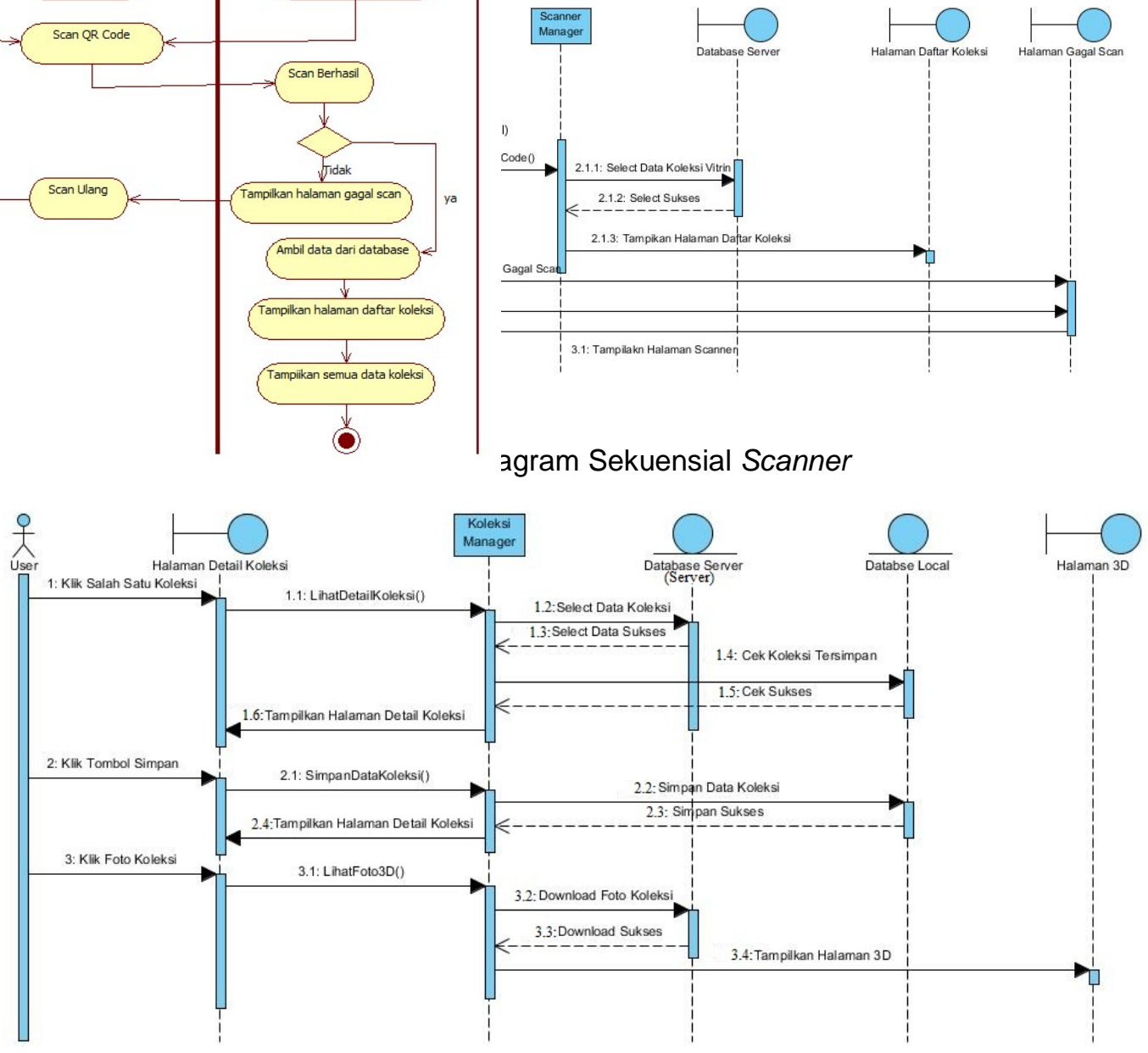

Gambar 2.4 Diagram SekuensialLihat Detail Koleksi, Simpan Koleksi Dan Lihat Foto 3D

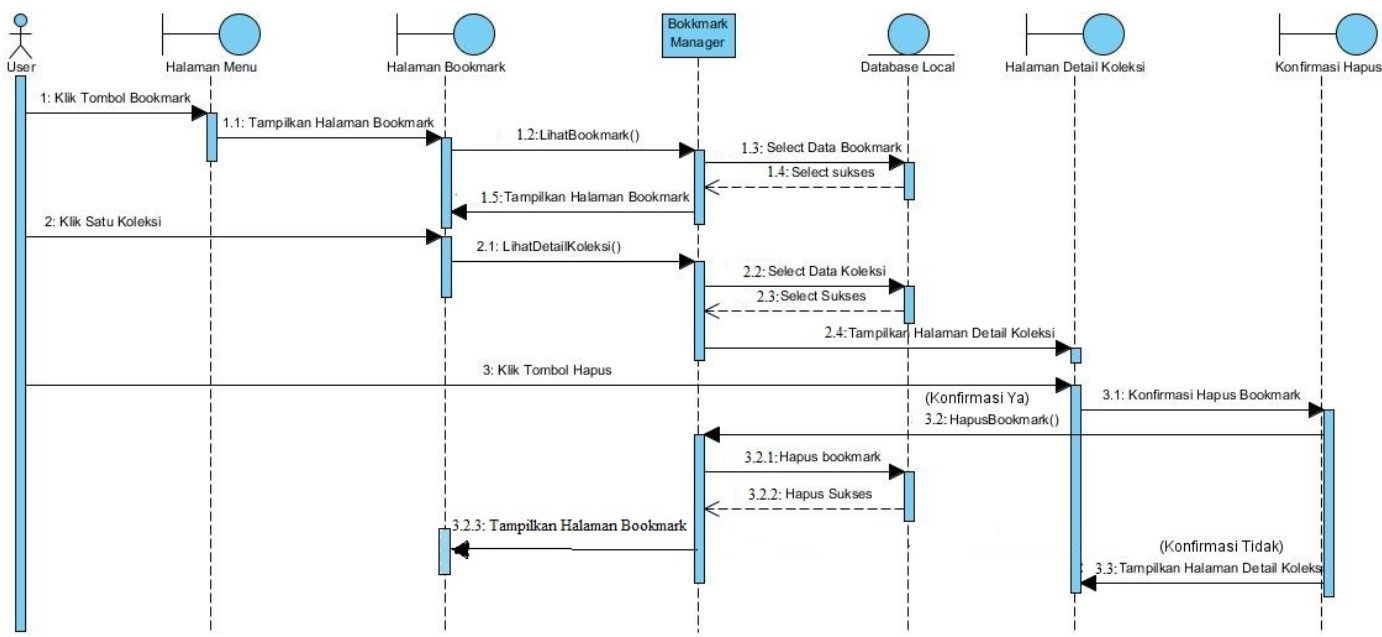

Gambar 2.5 Diagram Sekuensial Lihat Bookmark, Lihat Detail, Dan Hapus Data Koleksi 


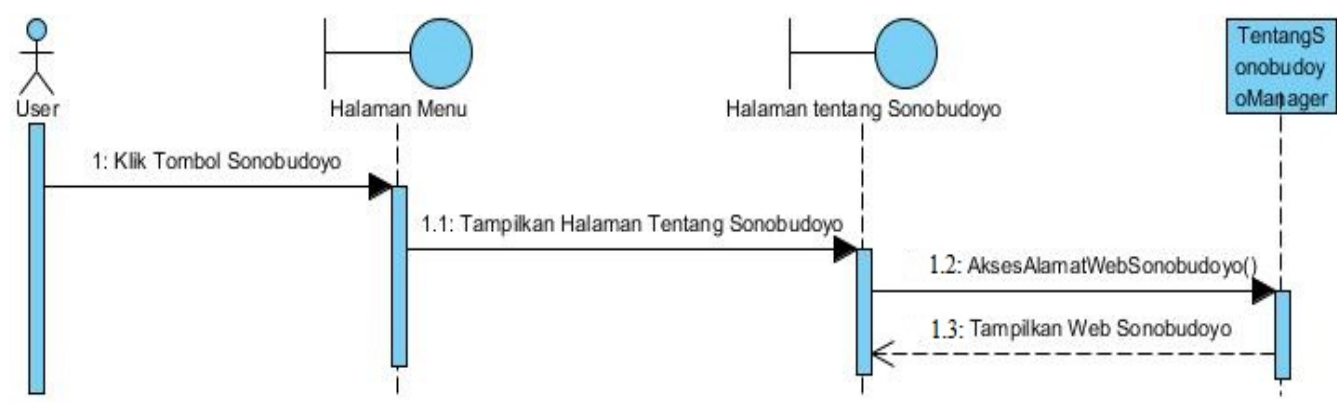

Gambar 2.6 Diagram Lihat Tentang Sonobudoyo

\section{Hasil Pembahasan}

Tahap pembuatan aplikasi QR Code Scannerini adalah hasil dari tahap rancangan aplikasi yang telah dibangun yaitu:

1. Tampilan awal

Tampilan awal aplikasi ini adalah tampilan pertama kali ketika aplikasi dijalankan yaitu terdapat menu berupa Scanner, Bookmark, Sonobudoyo, dan Tentang. Sedangkan halaman utama di isi dengan halaman Bookmark untuk menyimpan daftar koleksi yang telah tersimpan dalam database lokal. Tampilan awal dapat dilihat pada gambar 3.1.

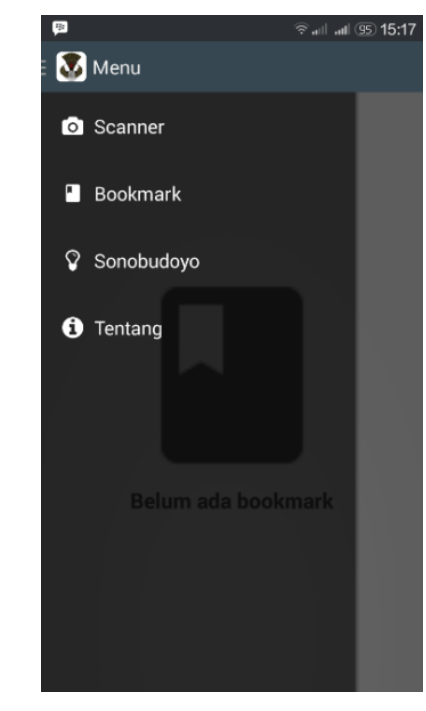

Gambar 3.1 Tampilan Awal

\section{Tampilan Scanner}

Tampilanscanner untuk menampilkan halaman kamera scan QR Code serta masih ditampilkan menu apabila user ingin memilih mengakses menu lain. Tampilanscanner dapat dilihat pada gambar 3.2. 


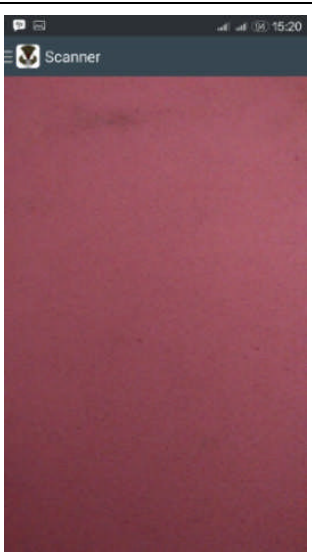

\section{Gambar 3.2 Tampilan Scanner}

Apabila proses scan QR Code gagal makan akan ditampilkan pesan harap scan id lokasi yang benar dan akan ditampilkan tombol untuk kembali scan QR Code. Tampilan gagal scan QR Codedapat dilihat pada gambar 3.3.

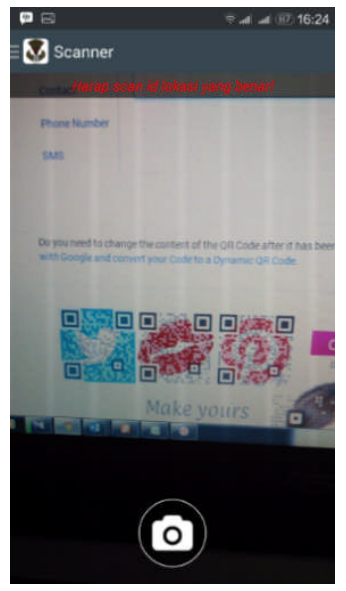

\section{Gambar 3.3 Tampilan Gagal Scan QR Code}

Potongan kode program untuk proses scan QR Codepenulis sajikan pada list 1

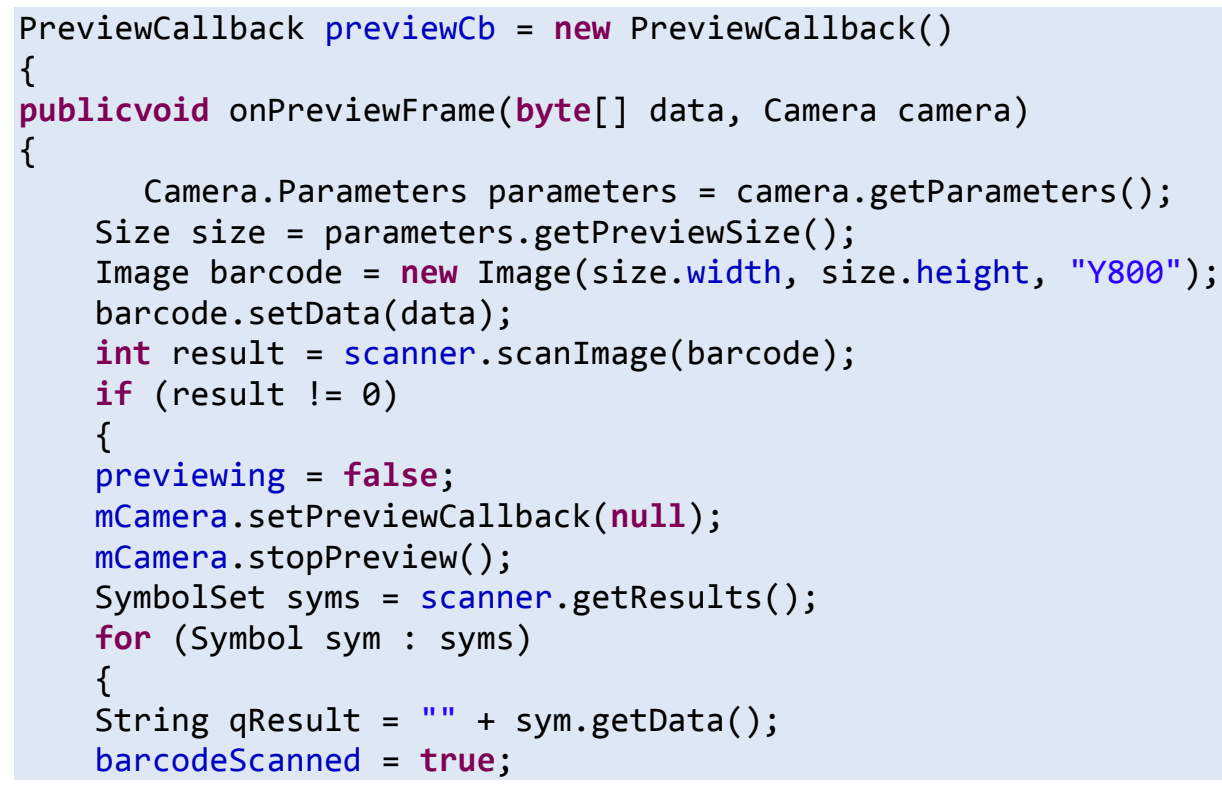




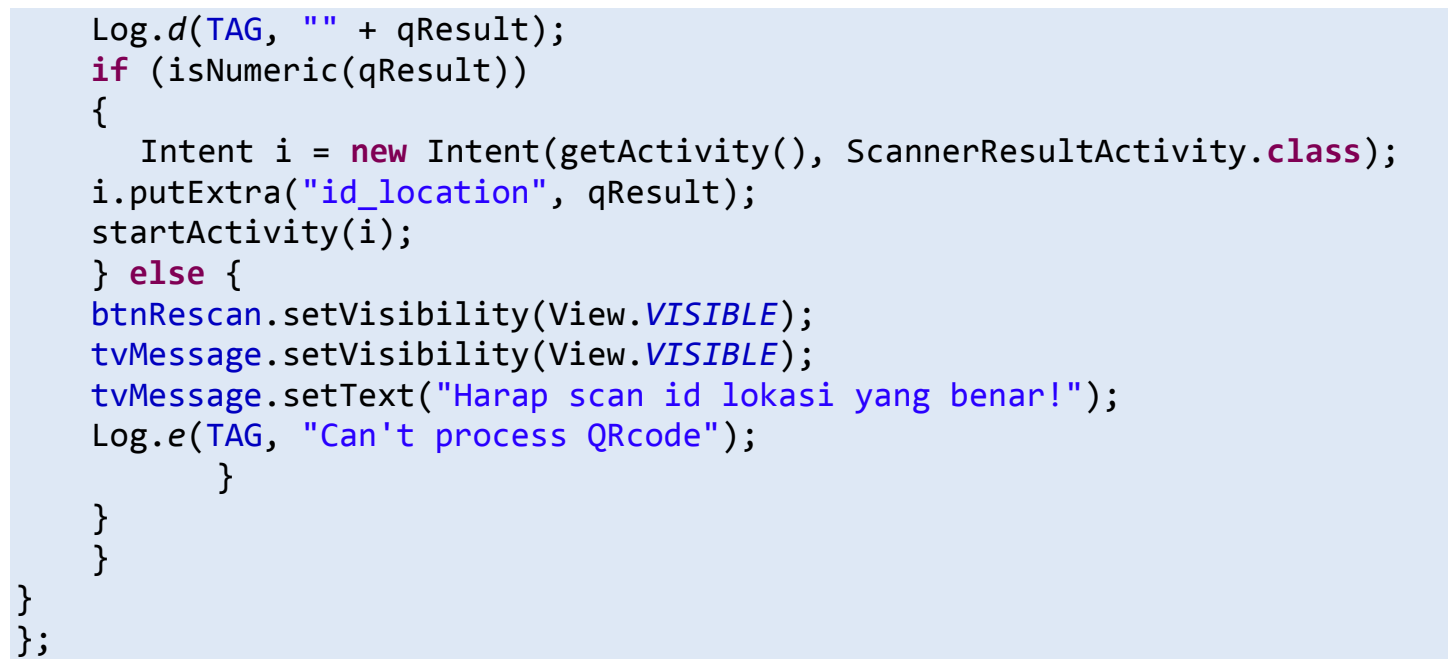

\section{List 1.Proses Scan QR Code}

Sedangkan potongan kode untuk mengeset kameraagarautofokus secara terus menerus penulis sajikan pada list 2

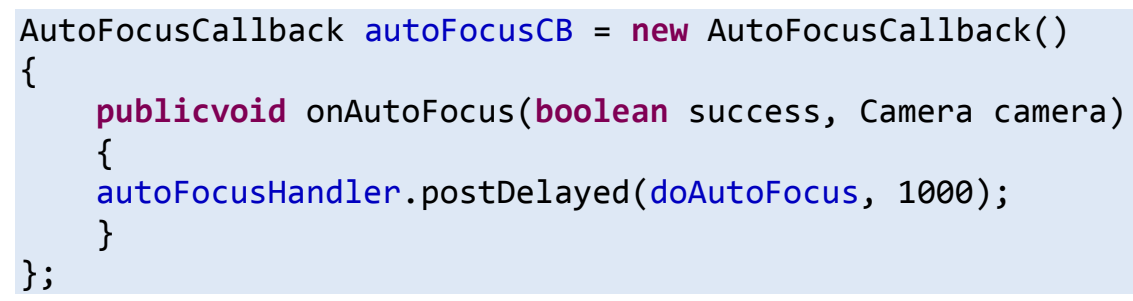

List 2.Mengeset Kamera Autofokus

\section{Tampilan Daftar Koleksi}

Tampilan daftar koleksi untuk menampilkan halaman daftar koleksi vitrin hasil dari proses scanner. Dalam halaman ini juga ditampilkan tombol untuk kembali ke halaman scanner. Tampilan daftar koleksidapat dilihat pada gambar 3.4.

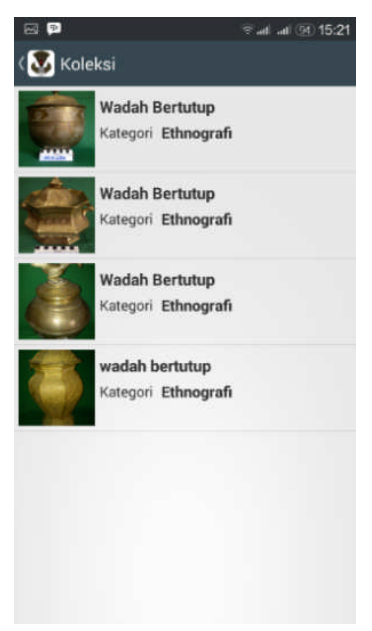

Gambar 3.4 Tampilan Daftar Koleksi

Potongan kode program prosesdaftar koleksi untukmengunduh data dari serverpenulis sajikan pada list 3 


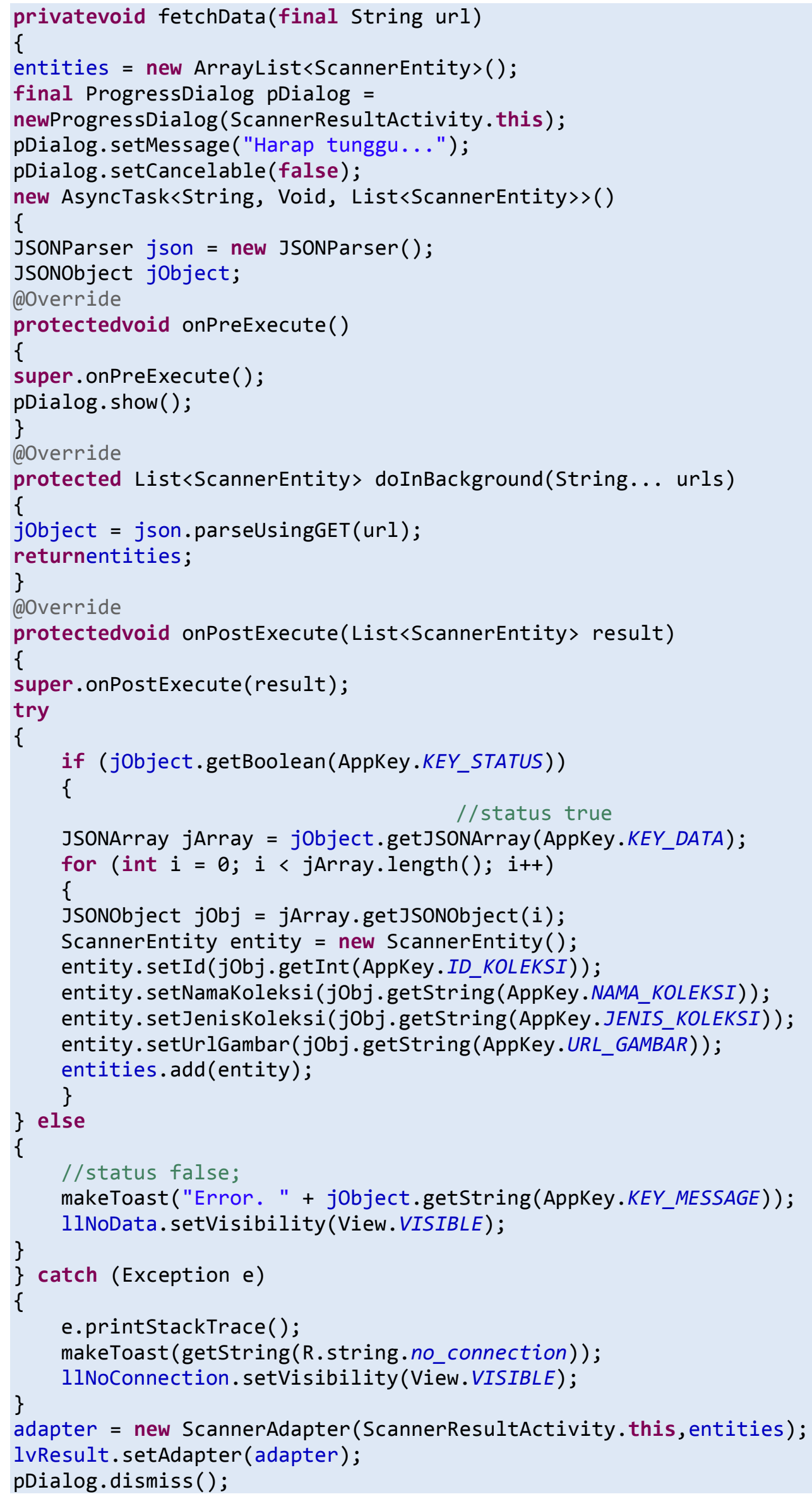




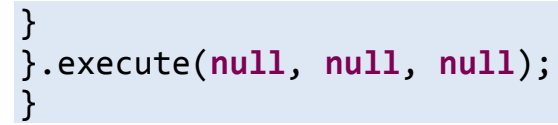

List 3.Proses Dafttar Koleksi Mengunduh Data dari Server

\section{Tampilan Detail Koleski}

Tampilan detail koleksi untuk menampilkan halaman informasi detail koleksi. Dalam halaman ini ditampilkan tombol untuk kembali ke halaman sebelumnya serta ditampilkan menu simpan untuk menyimpan koleksi ke database lokal. Tampilan detail koleksidengan tombol simpan dapat dilihat pada gambar 3.5

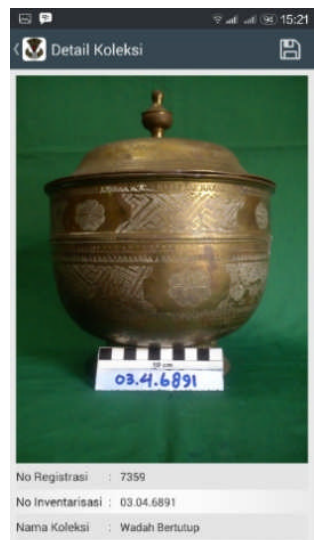

Gambar 3.5 Tampilan Detail Koleksi dengan Tombol Simpan

Apabila koleksi sudah tersimpan dalam Bookmark maka tombol simpan tidak ditampilkan. Tampilan detail koleksitanpa tombol simpan dapat dilihat pada gambar 3.6.

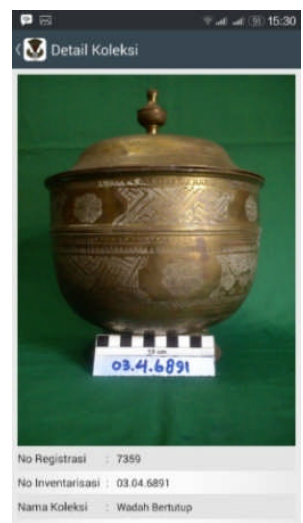

Gambar 3.6 Tampilan Detail Koleksi Tanpa Tombol Simpan

Potongan kode program prosesdetail koleksi untuk mengunduh data dari serverpenulis sajikan pada list 4 .

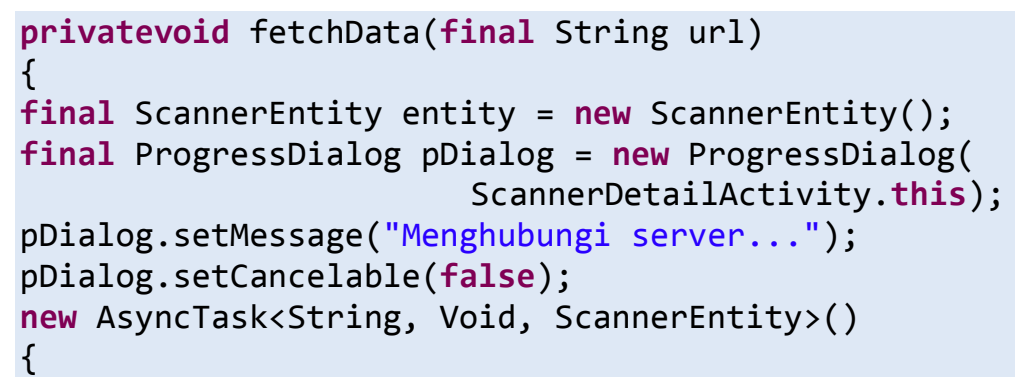




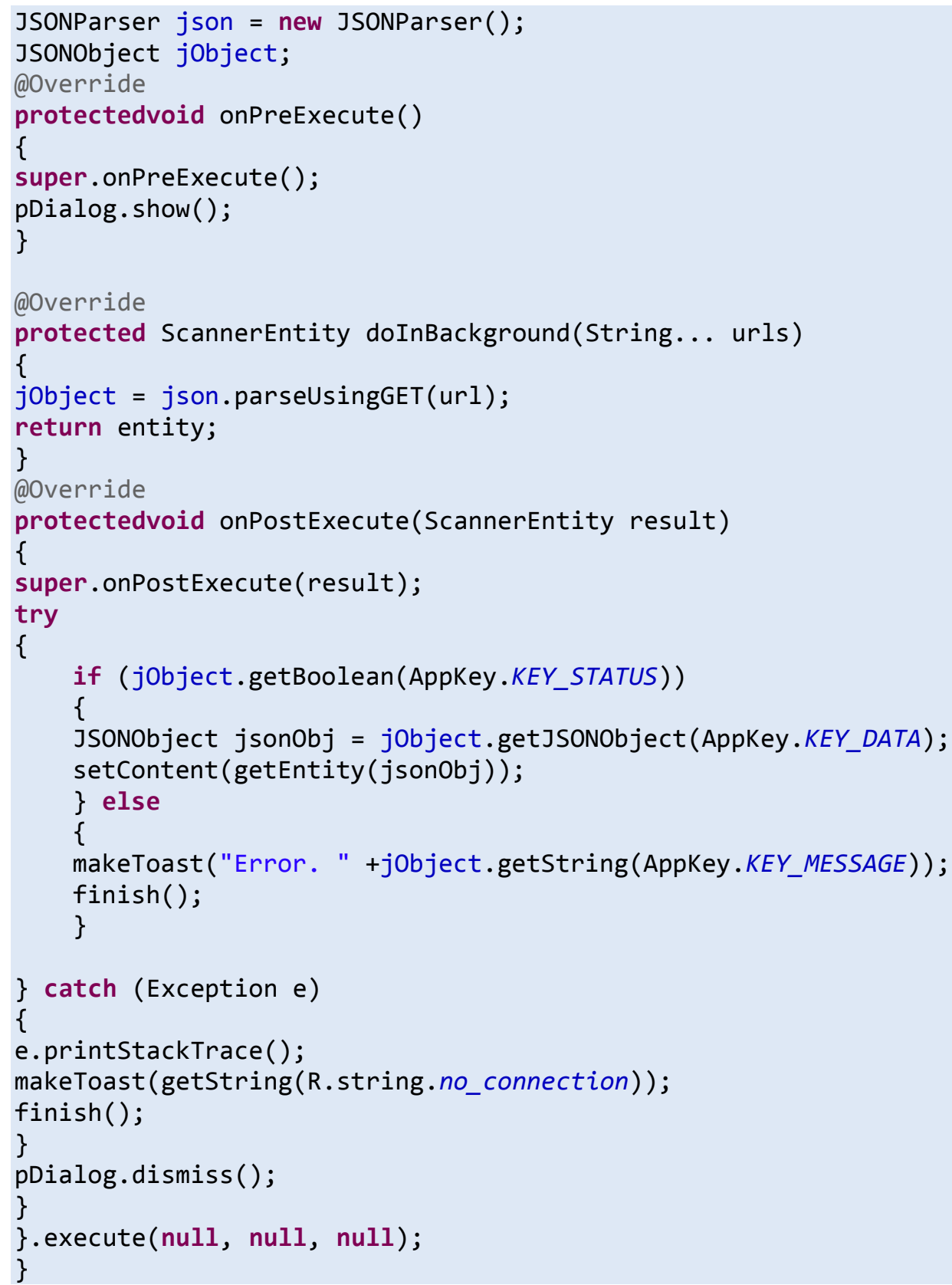

List 4.Proses Detail Koleksi Mengunduh Data dari Server

Hasil pengujian aplha aplikasi scanner dapat dilihat pada tabel 1.

Tabel 1 Hasil Pengujian Alpha

\begin{tabular}{|l|l|l|l|}
\hline No & Detail Item & Detail Pengujian & Penilaian \\
\hline 1. & Scanner & Scan QR Code & Berhasil \\
\hline & & $\begin{array}{l}\text { Pesan Eror dan Scan } \\
\text { Ulang QR Code }\end{array}$ & Berhasil \\
\hline & & $\begin{array}{l}\text { Tampilkan Detail } \\
\text { Koleksi }\end{array}$ & Berhasil \\
\hline 2. & Sookmark & $\begin{array}{l}\text { Tampan Koleksi } \\
\text { Tampilkan 3D Rotate } \\
\text { daftar koleksi }\end{array}$ & Berhasil \\
\hline
\end{tabular}




\begin{tabular}{|l|l|l|l|}
\hline & & $\begin{array}{l}\text { Tampilkan Detail } \\
\text { Koleksi }\end{array}$ & Berhasil \\
\hline 3. & Sonobudoyo & $\begin{array}{l}\text { Hapus Koleksi } \\
\text { Tampilkan Web } \\
\text { Sonobudoyo }\end{array}$ & Berhasil \\
\hline 4. & Tentang & $\begin{array}{l}\text { Tampilkan Halaman } \\
\text { Tentang Aplikasi }\end{array}$ & Berhasil \\
\hline
\end{tabular}

Hasil Pengujian Beta adalah Keenam belas responden mengisi kuisioner secara obyektif setelah melakukan pengujian dengan mengoperasikan sistem secara langsung. Hasil pengujian beta aplikasi scannerdapat dilihat pada tabel 2 dan 3.

Tabel 2 Hasil Pengujian Fungsionalitas Aplikasi

\begin{tabular}{|l|l|c|c|}
\hline \multirow{2}{*}{ No } & \multicolumn{1}{|c|}{ Item Uji } & \multicolumn{2}{|c|}{ Penilaian } \\
\cline { 2 - 4 } & $\begin{array}{l}\text { Ya } \\
\text { Aplikasi dapat melakukan scan QR Code dengan } \\
\text { benar }\end{array}$ & 16 & 0 \\
\hline 2. & $\begin{array}{l}\text { Aplikasi dapat melakukan scan ulang ketika gagal } \\
\text { scan QR Code }\end{array}$ & 16 & 0 \\
\hline 3. & $\begin{array}{l}\text { Aplikasi dapat menampilkan data detail informasi } \\
\text { koleksi }\end{array}$ & 16 & 0 \\
\hline 4. & $\begin{array}{l}\text { Aplikasi dapat menyimpan data koleksi ke dalam } \\
\text { Bookmark }\end{array}$ & 16 & 0 \\
\hline 5. & Aplikasi dapat menampilkan foto 3D Rotate & 16 & 0 \\
\hline 6. & $\begin{array}{l}\text { Aplikasi dapat menampilkan daftar koleksi yang ada } \\
\text { dalam Bookmark }\end{array}$ & 16 & 0 \\
\hline 7. & $\begin{array}{l}\text { Aplikasi dapat menampilkan detail koleksi yang ada } \\
\text { dalam Bookmark }\end{array}$ & 16 & 0 \\
\hline 8. & $\begin{array}{l}\text { Aplikasi dapat menghapus data koleksi yang terdapat } \\
\text { dalam Bookmark }\end{array}$ & 16 & 0 \\
\hline 9. & Aplikasi dapat menampilkan halaman web sonobudoyo & 16 & 0 \\
\hline 10. & Aplikasi dapat menampilkan informasi tentang aplikasi & 16 & 0 \\
\hline \multicolumn{2}{|l|}{ Total } & 160 & 0 \\
\hline
\end{tabular}

Untuk menentukan persentase dari tiap jawaban pada kuisioner pengujian fungsionalitas aplikasi digunakan rumus sebagai berikut:

$$
\text { Persentase jawaban }=\frac{\text { total skor jawaban }}{(\text { jumlah responden } x \text { jumlah pertanyaan })} \times 100 \%
$$

Berdasarkan rumus di atas, perhitungan persentase untuk jawaban "Ya" pada pengujian fungsionalitas aplikasi adalah sebagai berikut:

$$
\text { Persentase } Y a=\frac{160}{(16 \times 10)} \times 100 \%=100 \%
$$

Sedangkan perhitungan persentase untuk jawaban "Tidak" pada pengujian fungsionalitas aplikasi adalah sebagai berikut:

$$
\text { Persentase Tidak }=\frac{0}{(16 \times 10)} \times 100 \%=0 \%
$$


Tabel 3 Hasil Pengujian Antarmuka Aplikasi

\begin{tabular}{|l|l|l|l|l|l|l|}
\hline \multirow{2}{*}{ No } & \multicolumn{1}{|c|}{ Item Uji } & \multicolumn{5}{c|}{ Penilaian } \\
\cline { 3 - 8 } & \multicolumn{1}{|c|}{ SS } & S & N & TS & STS \\
\hline 1. & Aplikasi memiliki tampilan yang menarik & 1 & 9 & 6 & 0 & 0 \\
\hline 2. & Aplikasi mudah digunakan / dioperasikan & 5 & 11 & 0 & 0 & 0 \\
\hline 3. & $\begin{array}{l}\text { Aplikasi menampilkan foto 3D Rotate dengan } \\
\text { jelas }\end{array}$ & 3 & 12 & 1 & 0 & 0 \\
\hline 4. & $\begin{array}{l}\text { Aplikasi menampilkan proses loading download } \\
\text { foto dengan jelas }\end{array}$ & 6 & 10 & 0 & 0 & 0 \\
\hline 5. & Aplikasi menampilkan foto dengan jelas & 4 & 12 & 0 & 0 & 0 \\
\hline \multicolumn{2}{|c|}{ Total } & 19 & 52 & 7 & 0 & 0 \\
\hline
\end{tabular}

Keterangan:

$\begin{array}{lll}\text { SS = Sangat Setuju } & \text { TS = Tidak Setuju } & N=\text { Netral } \\ S=\text { Setuju } & \text { STS = Sangat Tidak Setuju } & \end{array}$

Tabel 4 Skor Kriteria Pengujian Antarmuka Aplikasi

\begin{tabular}{|l|l|l|}
\hline \multicolumn{1}{|c|}{ Skala Likert } & \multicolumn{1}{c|}{ Skor } & \multicolumn{1}{c|}{ Skala Kepuasan } \\
\hline Sangat Setuju & $5 \times 16=80$ & Sangat Puas \\
\hline Setuju & $4 \times 16=64$ & Puas \\
\hline Netral & $3 \times 16=48$ & Cukup \\
\hline Tidak Setuju & $2 \times 16=32$ & Tidak Puas \\
\hline Sangat Tidak Setuju & $1 \times 16=16$ & Sangat Tidak Puas \\
\hline
\end{tabular}

Untuk menentukan jarak interval antar total skor dapat digunakan rumus seperti berikut:

$$
\text { Jarak Interval }=\frac{\text { Total skor max }- \text { Total Scor min }}{\text { Jumlah skala }}
$$

Berdasarkan rumus di atas, maka didapatkan nilai jarak interval sebagai berikut:

$$
\text { Jarak Interval }=\frac{80-16}{5}=12.8
$$

Setelah mendapatkan nilai jarak interval yakni 12.8 maka skala rating kepuasan responden dapat dilihat pada tabel 5

Tabel 5 Skala Rating Kepuasan Koresponden

\begin{tabular}{|l|l|}
\hline \multicolumn{1}{|c|}{ Interval Skor } & \multicolumn{1}{c|}{ Skala Rating } \\
\hline $67.21-80.00$ & Sangat Puas \\
\hline $54.41-67.20$ & Puas \\
\hline $41.61-54.40$ & Cukup \\
\hline $28.81-41.60$ & Tidak Puas \\
\hline $16-28.80$ & Sangat Tidak Puas \\
\hline
\end{tabular}

Setelah menentukan skor kriteria dan skala rating kepuasan koresponden, langkah selanjutnya adalah menghitung skor jawaban dari tiap item uji pada kuisioner. Skor jawaban tiap item uji dapat dilihat pada tabel 6 .

Tabel 6 Skor Jawaban Item Uji

\begin{tabular}{|c|c|c|c|l|c|c|c|}
\hline No & Item Uji & \multicolumn{5}{|c|}{ Skor } & Jumlah \\
\cline { 3 - 7 } & & SS & S & N & TS & STS & Skor \\
\hline 1 & Soal 1 & $1 \times 5=5$ & $9 \times 4=36$ & $6 \times 3=18$ & $0 \times 2=0$ & $0 \times 1=0$ & 59 \\
\hline 2 & Soal 2 & $5 \times 5=25$ & $11 \times 4=44$ & $0 \times 3=0$ & $0 \times 2=0$ & $0 \times 1=0$ & 69 \\
\hline 3 & Soal 3 & $3 \times 5=15$ & $12 \times 4=48$ & $1 \times 3=3$ & $0 \times 2=0$ & $0 \times 1=0$ & 66 \\
\hline
\end{tabular}




\begin{tabular}{|l|l|l|l|l|l|l|l|}
\hline 4 & Soal 4 & $6 \times 5=30$ & $10 \times 4=40$ & $0 \times 3=0$ & $0 \times 2=0$ & $0 \times 1=0$ & 70 \\
\hline 5 & Soal 5 & $4 \times 5=20$ & $12 \times 4=48$ & $0 \times 3=0$ & $0 \times 2=0$ & $0 \times 1=0$ & 68 \\
\hline
\end{tabular}

Tahap terkahir adalah menghitung skor total dari jumlah skor tiap item uji. Rumus untuk menghitung skor total item uji adalah sebagai berikut:

$$
\text { Skor total }=\frac{\text { Jumlah skor soal } 1+\cdots+\text { Jumlah skor soal ke n }}{\text { Jumlah soal }}
$$
yaitu:

Berdasarkan rumus di atas, maka didapat nilai skor total dari pengujian antarmuka aplikasi

$$
\text { Skor total }=\frac{59+69+66+70+68}{5}=66.4
$$

Setelah dilakukan perhitungan skor total dari pengujian antarmuka sistem dengan hasil skor yaitu 66.4 yang berada pada skala rating antara 54.41 - 67.20 (Puas). Maka dapat disimpulkan bahwa responden merasa puas dengan antarmuka sistem, sehingga antarmuka sistem layak untuk diimplementasikan pada sistem.

\section{Kesimpulan}

Setelah dilakukan penelitian QR Code Scanner ini, maka didapatkan beberapa kesimpulan yaitu:

1. Aplikasi QR Code Scanner yang dibangun berbasis Android menggunakan ZBar Library mempunyai fitur Scanner, Bookmark, tentang Museum Sonobudoyo, dan menampilkan foto koleksi secara 3D Rotate. Semua fitur dalam aplikasi ini dapat berjalan dengan baik.

2. Hasil pengujian alpha adalah semua proses dalam aplikasi berhasil dijalankan saat dilakukan pengujian. Pengujian beta pada fungsionalitas aplikasi didapatkan 100\% responden menyatakan "Ya", dan $0 \%$ responden menyatakan "Tidak". Sedangkan pengujian beta pada antarmuka sistem dengan hasil skor yaitu 66.4 yang berada pada skala rating antara $54.41-67.20$ adalah puas

\section{Daftar Pustaka}

Dharwiyanti, S. (2003). Pengantar Unified Modeling Language (UML).Sumber: http://www.unej.ac.id/pdf/yanti-uml.pdf

Flannery, S. (2011). QR Barcode Detection.Sumber: www.pixeltangent.com/downloads/qr_detection.ppt

Guna, G. E. (2014). Pembangunan Aplikasi Web Pemesanan Makanan Menggunakan QR Code. Yogyakarta: Universitas Atma Jaya.

Harahap, N. S. (2011). Pemrograman Aplikasi Mobile Smartphone dan Tablet PC Berbasis Android. Bandung: Informatika.

Hariyanto, B. (2010). Esensi-esensi Bahasa Pemrograman Java. Bandung: Informatika.

Haryono, A. H. (2007). Mudah Belajar JAVA. Bandung: Informatika.

Denso Wave Inc.http://www.denso-wave.com/qrcode/aboutqr-e.html (diakses 20 Desember 2014)

Json. http://www.json.org (diakses 20 Desember 2014)

Junaedi, M. (2003). Pengantar XML.Sumber: http://ikc.dinus.ac.id/umum/junaedi/junaedi-xml.zip

Kurniati, A. (2011). Penerapan Aplikasi QR Code Reader dan QR code Generator Secara Mobile untuk Mengelola Benda Cagar Budaya Kota Salatiga. Salatiga: Universitas Kristen Satya Wacana.

Rizky, A. B. (2010). Aplikasi Mobile dengan Barcode 2D untuk Informasi Biodiversitas. Depok: Universitas Gunadarma.

Saputro, R. H. (2013). Aplikasi Pembacaan QR Code dengan Blackberry Z10. Depok: Universitas Gunadarma .

Setyawan, A. H. (2013). Perancangan Aplikasi Sistem Presensi Mahasiswa Menggunakan Qr Code Pada Sistem Operasi Android. Semarang: Universitas Diponegoro. 